\title{
New Guaianolide-Type Sesquiterpene Lactones from Inula verbascifolia
}

\author{
Abou El-Hamd H. Mohamed ${ }^{\mathrm{a}, *}$, Hosam-Eldin H. Mahmoud ${ }^{\mathrm{b}}$, \\ Fathy F. Abdellatif ${ }^{c}$, Yousif S. Mohamed ${ }^{c}$, the late Ahmed A. Ahmed ${ }^{c}$, \\ and Shinji Ohta ${ }^{\mathrm{d}}$ \\ a Chemistry Department, Faculty of Science, Aswan University, Aswan, Egypt. \\ Fax:+973480450. E-mail: abouhassan68@yahoo.com \\ b Medical Chemistry Department, Faculty of Medicine, Jazan University, \\ Jazan, Saudi Arabia \\ c Chemistry Department, Faculty of Science, El-Minia University, El-Minia, Egypt \\ d Nagahama Institute of Bio-Science and Technology, Nagahama, Shiga 526-0829, Japan \\ * Author for correspondence and reprint requests \\ Z. Naturforsch. 68c, 175 -180 (2013); received December 12, 2012/May 8, 2013
}

The aerial parts of Inula verbascifolia afforded two new guaianolide-type sesquiterpene lactones. Their structures were determined by spectroscopic methods (IR, MS, ${ }^{1} \mathrm{H}$ NMR, ${ }^{13} \mathrm{C}$ NMR, DEPT, ${ }^{1} \mathrm{H}-{ }^{1} \mathrm{H}$ COSY, HMQC, and HMBC).

Key words: Asteraceae, Inula, Sesquiterpene Lactones

\section{Introduction}

The genus Inula (family Asteraceae, tribe Inuleae) with about $80-100$ species represents a poorly delineated complex (Merxmüller et al., 1977). Chemical investigations of some members of the genus showed that there are two main groups, one containing simple sesquiterpene lactones, especially eudesmanolides, and the second containing simple thymol derivatives (Bohlmann and Zdero, 1977). Plants of the genus Inula have been shown to contain high levels of sesquiterpene lactones and have recently received considerable attention due to their antineoplastic and anti-inflammatory effects (Cheng et al., 2011; Harvala et al., 2002; Hua et al., 2012; Kang et al., 2004; Konishi et al., 2002; Li et al., 2012; Qin et al., 2012; Won et al., 2004; Chia and Hsin, 2007). In continuation of our investigation of the medicinal plants of the Asteraceae family (Ahmed $e t$ al., 2003), we investigated the chemical constituents of I. verbascifolia. (Willd.) Hausskn. subsp. methanea (Hausskn.) Tutin, which is endemic in Central and South Greece (Ball and Tutin, 1976).

\section{Results and Discussion}

The methylene chloride extract of the air-dried aerial parts of Inula verbascifolia was chromatographed on silica gel and Sephadex LH-20 columns to give two new sesquiterpenes, $\mathbf{1}$ and 2. Compound $\mathbf{1}$ was obtained as a yellowish oil, $[\alpha]_{\mathrm{D}}^{25}=-20.88^{\circ}(c 0.015, \mathrm{MeOH})$, and its IR spectrum showed absorption bands at $3471 \mathrm{~cm}^{-1}(\mathrm{OH})$ and $1763 \mathrm{~cm}^{-1}(\mathrm{C}=\mathrm{O})$. Complete structural information was obtained from ${ }^{1} \mathrm{H}$ NMR, ${ }^{13} \mathrm{C}$ NMR, DEPT, ${ }^{1} \mathrm{H}-{ }^{1} \mathrm{H}$ COSY, HMQC, HMBC, NOESY, and mass spectra. The ESITOF mass spectrum of $\mathbf{1}$ exhibited a molecular ion peak $[\mathrm{M}+\mathrm{Na}]^{+}$at $\mathrm{m} / z 271$ and the exact mass was determined at $m / z$ 271.1310, establishing the elemental composition $\mathrm{C}_{15} \mathrm{H}_{20} \mathrm{O}_{3} \mathrm{Na}$, confirming that the molecular formula of $\mathbf{1}$ is $\mathrm{C}_{15} \mathrm{H}_{20} \mathrm{O}_{3}$. Two fragments were apparent at $\mathrm{m} / z, 230$ and 215 resulting from loss of a water molecule and a methyl group, respectively, while the two fragments at $\mathrm{m} / z 202$ and 201 were attributed to the loss of $\mathrm{CO}$ and $\mathrm{CHO}$ groups, respectively. The ${ }^{1} \mathrm{H}$ and ${ }^{13} \mathrm{C}$ NMR spectroscopic data of $\mathbf{1}$ established the presence of a guaianolide-type sesquiterpene. The ${ }^{1} \mathrm{H}$ NMR spectrum indicated the presence of an olefinic proton at $\delta_{\mathrm{H}} 5.85 \mathrm{ppm}(\mathrm{d}, J=7.6 \mathrm{~Hz}, \mathrm{H}-9)$ and an olefinic methyl group at $\delta_{\mathrm{H}} 1.74 \mathrm{ppm}(\mathrm{s}, \mathrm{H}-14)$. A secondary methyl carbon atom appeared at $\delta_{\mathrm{H}}$ $1.12 \mathrm{ppm}(\mathrm{d}, J=6.9 \mathrm{~Hz})$, and correlated with a methyl carbon signal at $\delta_{\mathrm{C}} 12.20 \mathrm{ppm}$ in HMQC, $\mathrm{C}-13$, and with a multiplet signal at $\delta_{\mathrm{H}} 2.24 \mathrm{ppm}$ $(1 \mathrm{H}, \mathrm{m})$ in ${ }^{1} \mathrm{H}-{ }^{1} \mathrm{H}$ COSY, $\mathrm{H}-11$, suggesting an $\alpha$-methyl- $\gamma$-lactone. Moreover, the examination of 
the connectivities in the ${ }^{1} \mathrm{H}-{ }^{1} \mathrm{H}$ COSY spectrum of compound $\mathbf{1}$ indicated strong correlations between the signal at $\delta_{\mathrm{H}} 4.58 \mathrm{ppm}(1 \mathrm{H}, \mathrm{t}, J=$ $10.2 \mathrm{~Hz}, \mathrm{H}-6)$ with the signals at $\delta_{\mathrm{H}} 2.42 \mathrm{ppm}(1 \mathrm{H}$, $\mathrm{dd}, J=10.2,7.9 \mathrm{~Hz}, \mathrm{H}-5)$ and $1.87 \mathrm{ppm}(1 \mathrm{H}, \mathrm{t}, J=$ $11.5 \mathrm{~Hz}, \mathrm{H}-7)$, suggesting the presence of a $\mathrm{C} 5 \mathrm{H}-$ $\mathrm{C} 6 \mathrm{H}(\mathrm{O})-\mathrm{C} 7 \mathrm{H}$ moiety. Additionally, the signal at $\delta_{\mathrm{H}} 4.24 \mathrm{ppm}(1 \mathrm{H}, \mathrm{d}, J=7.6 \mathrm{~Hz}, \mathrm{H}-8)$ correlated with two signals at $\delta_{\mathrm{H}} 1.87 \mathrm{ppm}(1 \mathrm{H}, \mathrm{t}, J=11.5 \mathrm{~Hz}$, $\mathrm{H}-7)$ and $5.85 \mathrm{ppm}(1 \mathrm{H}, \mathrm{d}, J=7.6 \mathrm{~Hz}, \mathrm{H}-9)$, indicating the presence of a $\mathrm{C} 7(\mathrm{H})-\mathrm{C} 8 \mathrm{H}(\mathrm{O})-\mathrm{C} 9 \mathrm{H}$ moiety. Accordingly, compound $\mathbf{1}$ contained a $\mathrm{C} 5 \mathrm{H}-\mathrm{C} 6 \mathrm{H}(\mathrm{O})-\mathrm{C} 7 \mathrm{H}-\mathrm{C} 8 \mathrm{H}(\mathrm{O})-\mathrm{C} 9 \mathrm{H}$ moiety. The ${ }^{13} \mathrm{C}$ NMR spectroscopic data revealed 15 carbon atoms while their multiplicities (by DEPT analysis) confirmed the number of hydrogen atoms of the formula given above. The carbon atoms were assigned as two methyl, three methylene, seven methine, and three quaternary carbon atoms. The other proton and carbon signals are listed in the Table I. Moreover, all proton and carbon signals were determined by ${ }^{1} \mathrm{H}-{ }^{1} \mathrm{H}$ COSY, HMQC, and HMBC. The connectivities of the moieties, the position of the hydroxy group, and the lactonization were established by the HMBC spectrum, the most important correlations were found be- tween: H-1 $\left(\delta_{\mathrm{H}} 2.90 \mathrm{ppm}\right)$ with C-2 $\left(\delta_{\mathrm{C}} 28.99 \mathrm{ppm}\right)$, C-5 $\left(\delta_{\mathrm{C}} 50.91 \mathrm{ppm}\right), \mathrm{C}-6\left(\delta_{\mathrm{C}} 81.74 \mathrm{ppm}\right), \mathrm{C}-9\left(\delta_{\mathrm{C}}\right.$ $126.92 \mathrm{ppm}), \mathrm{C}-10 \quad\left(\delta_{\mathrm{C}} 144.87 \mathrm{ppm}\right)$, and $\mathrm{H}-6$ $\left(\delta_{\mathrm{H}} 4.58 \mathrm{ppm}\right)$ with $\mathrm{C}-4 \quad\left(\delta_{\mathrm{C}} 149.81 \mathrm{ppm}\right), \mathrm{C}-8$ $\left(\delta_{\mathrm{C}} 63.43 \mathrm{ppm}\right), \mathrm{C}-11\left(\delta_{\mathrm{C}} 37.62 \mathrm{ppm}\right)$, and $\mathrm{H}-7$ $\left(\delta_{\mathrm{H}} 1.87 \mathrm{ppm}\right)$ with $\mathrm{C}-5 \quad\left(\delta_{\mathrm{C}} 50.91 \mathrm{ppm}\right), \mathrm{C}-11$ $\left(\delta_{\mathrm{C}} 37.62 \mathrm{ppm}\right), \mathrm{C}-13\left(\delta_{\mathrm{C}} 12.20 \mathrm{ppm}\right)$, and $\mathrm{H}-14$ $\left(\delta_{\mathrm{H}} 1.74 \mathrm{ppm}\right)$ with $\mathrm{C}-1 \quad\left(\delta_{\mathrm{C}} 44.61 \mathrm{ppm}\right), \mathrm{C}-9$ $\left(\delta_{\mathrm{C}} 126.92 \mathrm{ppm}\right), \mathrm{C}-10\left(\delta_{\mathrm{C}} 144.87 \mathrm{ppm}\right)$, and $\mathrm{H}-15$ $\left(\delta_{\mathrm{H}} 5.05,5.43 \mathrm{ppm}\right)$ with $\mathrm{C}-3\left(\delta_{\mathrm{C}} 32.98 \mathrm{ppm}\right), \mathrm{C}-5$ $\left(\delta_{\mathrm{C}} 50.91 \mathrm{ppm}\right)$. The relative stereochemistry of $\mathbf{1}$ was established from the coupling constants and NOESY experiments. The relative configuration and stereochemistry at C-5, C-6, and C-7 were derived from the coupling constants $\left(J_{5,6}=10.2 \mathrm{~Hz}\right.$ and $J_{6,7}=11.5 \mathrm{~Hz}$ ), which were in agreement with the trans-diaxial disposition of the protons at C-5 $(\alpha)$, C-6 $(\beta)$, and C-7 $(\alpha)$. The NOESY experiments supported the proposed relative configuration by the following correlations: H-8 showed a crosspeak with H-11, whereas H-6 showed cross-peaks with $\mathrm{H}-1$ and $\mathrm{H}-11$, indicating the $\beta$-orientation of these protons. Furthermore, strong NOEs were observed between $\mathrm{H}-5, \mathrm{H}-7$, and $\mathrm{H}-2\left(\delta_{\mathrm{H}}\right.$ $1.68 \mathrm{ppm})$, suggesting the $\alpha$-orientation of these protons (Papano et al., 1980; Romo et al., 1968).

Table I. ${ }^{1} \mathrm{H}$ NMR (600 MHz, $\mathrm{CDCl}_{3}$ ) and ${ }^{13} \mathrm{C}$ NMR (125 MHz, $\mathrm{CDCl}_{3}$ ) spectroscopic data of compounds $\mathbf{1}$ and $\mathbf{2}^{\mathrm{a}}$.

\begin{tabular}{|c|c|c|c|c|c|c|c|}
\hline $\mathrm{H}$ & $\begin{array}{l}\delta_{\mathrm{H}} \\
\mathbf{1}\end{array}$ & $\begin{array}{l}\text { HMBC } \\
\text { correlations }\end{array}$ & $\delta_{\mathrm{H}}$ & $\begin{array}{l}\mathrm{HMBC} \\
\text { correlations }\end{array}$ & $\mathrm{C}$ & $\begin{array}{c}\delta_{\mathrm{C}} \\
\mathbf{1}\end{array}$ & $\begin{array}{c}\delta_{\mathrm{C}} \\
\mathbf{2}\end{array}$ \\
\hline $\mathrm{H}-1 \beta$ & $2.90 \mathrm{~m}$ & C-5, C-6, C-9, C-10 & $2.46 \mathrm{~m}$ & $\begin{array}{l}\text { C-2, C-5, C-6, } \\
\text { C-9, C-10 }\end{array}$ & $\mathrm{C}-1$ & 44.61 & 44.87 \\
\hline $\mathrm{H}-2 \alpha$ & $1.68 \mathrm{~m}$ & C-1, C-4, C-5 & 1. $65 \mathrm{~m}$ & $\begin{array}{l}\text { C-1, C-3, C-4, } \\
\text { C-5, C-10 }\end{array}$ & $\mathrm{C}-2$ & 28.99 & 29.00 \\
\hline $\mathrm{H}-2 \beta$ & $1.94 \mathrm{~m}$ & C-1, C-4, C-5 & $1.89 \mathrm{~m}$ & $\begin{array}{l}\text { C- } 1, \text { C-4, C-3, } \\
\text { C-5, C-10 }\end{array}$ & $\mathrm{C}-3$ & 32.98 & 35.02 \\
\hline $\mathrm{H}-3 \alpha$ & $2.45 \mathrm{~m}$ & C-1, C-4, C-5 & $2.40 \mathrm{dd}(14.6,6.0)$ & C-1, C-4, C-5 & C-4 & 149.81 & 152.12 \\
\hline $\mathrm{H}-3 \beta$ & $2.32 \mathrm{~m}$ & C-4 & $2.27 \mathrm{~m}$ & $\mathrm{C}-1, \mathrm{C}-4, \mathrm{C}-5$ & & & \\
\hline $\mathrm{H}-5 \alpha$ & $2.42 \mathrm{dd}(10.2,7.9)$ & $\mathrm{C}-4, \mathrm{C}-6$ & $2.02 \mathrm{t}(10.0)$ & C-4, C-6, C-15 & $\mathrm{C}-5$ & 50.91 & 52.59 \\
\hline H-6 $\beta$ & $4.58 \mathrm{t}(10.2)$ & $\begin{array}{l}\text { C-4, C-5, } \\
\text { C-8, C-11 }\end{array}$ & $3.57 \mathrm{t}(10.0)$ & $\begin{array}{l}\text { C-1, C-4, C-5, } \\
\text { C- } 8, \text { C-11 }\end{array}$ & C-6 & 81.74 & 77.91 \\
\hline $\mathrm{H}-7 \alpha$ & $1.87 \mathrm{t}(11.5)$ & C-11, C-13 & $1.82 \mathrm{dd}(10.4,10.0)$ & C-5, C-11, C-13 & $\mathrm{C}-7$ & 54.80 & 54.97 \\
\hline $\mathrm{H}-8 \beta$ & $4.24 \mathrm{~d}(7.6)$ & $\begin{array}{l}\text { C-6, C-7, C-9, C-10, } \\
\text { C-11 }\end{array}$ & $4.81 \mathrm{~d}(8.6)$ & $\begin{array}{l}\text { C-6, C-7, C-9, } \\
\text { C-10 }\end{array}$ & C-8 & 63.43 & 77.31 \\
\hline \multirow[t]{2}{*}{ H-9 } & \multirow[t]{2}{*}{$5.85 \mathrm{~d}(7.6)$} & \multirow[t]{2}{*}{ C-1, C-7, C-8, C-14 } & \multirow[t]{2}{*}{5.74 brs } & \multirow[t]{2}{*}{ C-1, C-14 } & C-9 & 126.92 & 125.43 \\
\hline & & & & & $\mathrm{C}-10$ & 144.87 & 139.92 \\
\hline \multirow[t]{2}{*}{$\mathrm{H}-11 \beta$} & \multirow[t]{2}{*}{$2.24 \mathrm{~m}$} & \multirow[t]{2}{*}{ C-8, C-13 } & \multirow[t]{2}{*}{$2.57 \mathrm{~m}$} & \multirow[t]{2}{*}{ C-6, C-7, C-13 } & C-11 & 37.62 & 42.00 \\
\hline & & & & & C-12 & 178.54 & 177.40 \\
\hline $\mathrm{H}-13 \alpha$ & $1.12 \mathrm{~d}(6.9)$ & C-7, C-11, C-12 & $1.42 \mathrm{~d}(7.0)$ & C-7, C-11, C-13 & C-13 & 12.20 & 15.71 \\
\hline $\mathrm{H}-14$ & $1.74 \mathrm{~s}$ & C-9, C-10 & $1.76 \mathrm{~s}$ & C-1, C-9, C-10 & C-14 & 23.10 & 20.00 \\
\hline H-15a & $5.05 \mathrm{~s}$ & $\mathrm{C}-4, \mathrm{C}-5$ & $5.02 \mathrm{~s}$ & $\mathrm{C}-3, \mathrm{C}-5$ & $\mathrm{C}-15$ & 110.75 & 109.81 \\
\hline $\mathrm{H}-15 b$ & $5.43 \mathrm{~s}$ & C-4 & $5.04 \mathrm{~s}$ & $\mathrm{C}-3, \mathrm{C}-5$ & & & \\
\hline
\end{tabular}

a TMS as internal standard. $J$ in $\mathrm{Hz}$. 
Thus, compound $\mathbf{1}$ was identified as $8 \alpha$-hydroxy$5 \alpha, 7 \alpha H$-guai-4(15),9(10)-dien-12,6 $\alpha$-olide (Fig. 1), a new natural product.

Compound 2 was obtained as yellowish material. Its EI mass spectrum exhibited a significant molecular ion peak $[\mathrm{M}]^{+}$at $m / z 248$, consistent with the molecular formula $\mathrm{C}_{15} \mathrm{H}_{20} \mathrm{O}_{3}$. The fragment ion at $\mathrm{m} / \mathrm{z}, 230$ was due to the elimination of a water molecule, suggesting that compound 2 contains one hydroxy group. Its IR spectrum showed absorption bands indicative of a $\gamma$-lactone group $\left(1754 \mathrm{~cm}^{-1}\right)$ and an aliphatic hydroxy group $\left(3475 \mathrm{~cm}^{-1}\right)$. Careful inspection of the ${ }^{1} \mathrm{H}$ NMR spectrum revealed that compound $\mathbf{2}$ is a sesquiterpene with a guaiane skeleton. The ${ }^{1} \mathrm{H}$ NMR and ${ }^{13} \mathrm{C}$ NMR spectroscopic data of $\mathbf{2}$ were very similar to those of $\mathbf{1}$, except that the signal of $\mathrm{H}-5$ of 2 appeared at higher field, $\delta_{\mathrm{H}} 2.02 \mathrm{ppm}(1 \mathrm{H}, \mathrm{t}$,
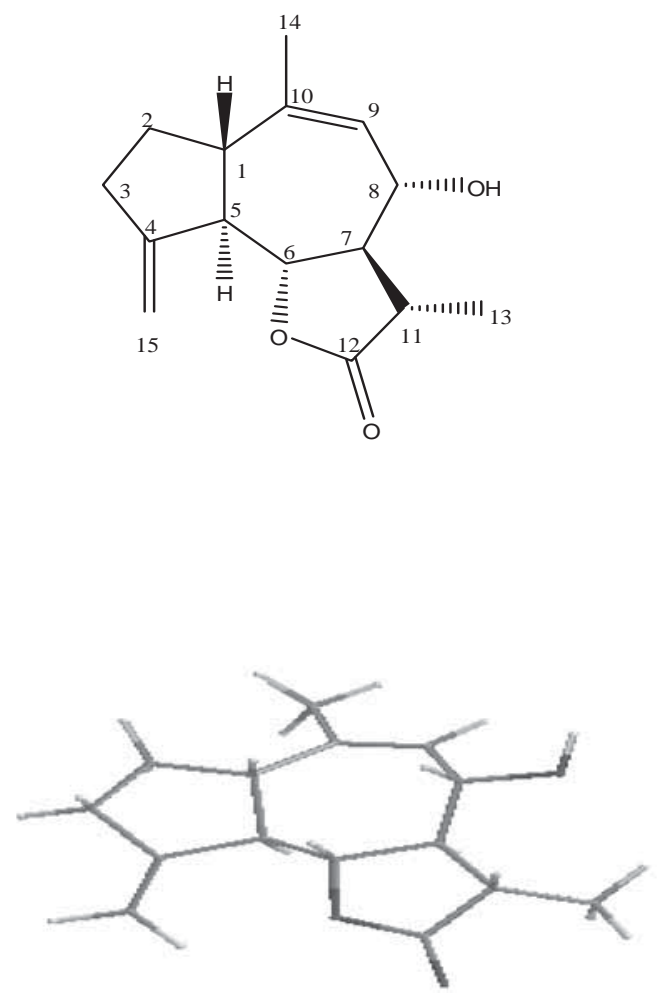

Compound 1
$\left.J=10.0 \mathrm{~Hz}, \delta_{\mathrm{C}} 52.59 \mathrm{ppm}\right)$, than the $\mathrm{H}-5$ signal of $1\left(\delta_{\mathrm{H}} 2.42 \mathrm{ppm}, \delta_{\mathrm{C}} 50.91 \mathrm{ppm}\right)$, and H-6 of 2 appeared more up-field at $\delta_{\mathrm{H}} 3.57 \mathrm{ppm}(1 \mathrm{H}, \mathrm{t}, J=$ $\left.10.0 \mathrm{~Hz}, \delta_{\mathrm{C}} 77.91 \mathrm{ppm}\right)$ than that of $\mathrm{H}-6$ in $\mathbf{1}\left(\delta_{\mathrm{H}}\right.$ $\left.4.58 \mathrm{ppm}, \delta_{\mathrm{C}} 81.74 \mathrm{ppm}\right)$, suggesting that the free hydroxy group is located at C- 6 . Also, the presence of $\mathrm{H}-8$ in compound 2 at $\delta_{\mathrm{H}} 4.81 \mathrm{ppm}(1 \mathrm{H}$, $\left.\mathrm{d}, J=8.6 \mathrm{~Hz}, \delta_{\mathrm{C}} 77.31 \mathrm{ppm}\right)$, down-field from the $\mathrm{H}-8$ signal of $1\left(\delta_{\mathrm{H}} 4.24 \mathrm{ppm}, \delta_{\mathrm{C}} 63.43 \mathrm{ppm}\right)$, indicated a C-7/C-8 trans-fused lactone ring. The other proton and carbon signals are listed in Table I. Moreover, all proton and carbon signals were determined by ${ }^{1} \mathrm{H}-{ }^{1} \mathrm{H}$ COSY, HMQC, and HMBC. Again, the connectivities of the moieties, the position of the hydroxy group, and the lactonization were established by the HMBC spectrum of $\mathbf{2}$, the most important correlations were found between: $\mathrm{H}-1 \quad\left(\delta_{\mathrm{H}} 2.46 \mathrm{ppm}\right)$ with $\mathrm{C}-2 \quad\left(\delta_{\mathrm{C}} 29.00 \mathrm{ppm}\right)$,
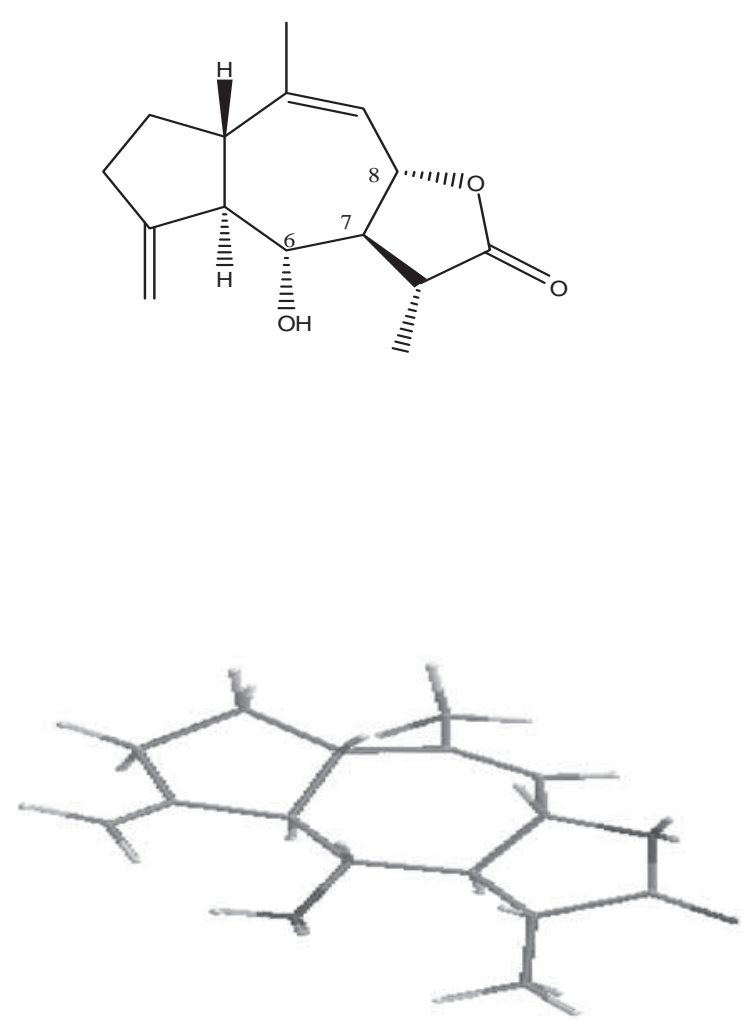

Compound 2

Fig. 1. Chemical structures an 3D diagrams of compounds $\mathbf{1}$ and $\mathbf{2}$. 
C-5 $\left(\delta_{\mathrm{C}} 52.59 \mathrm{ppm}\right), \mathrm{C}-6 \quad\left(\delta_{\mathrm{C}} 77.91 \mathrm{ppm}\right), \mathrm{C}-9$ $\left(\delta_{\mathrm{C}} 125.43 \mathrm{ppm}\right), \mathrm{C}-10\left(\delta_{\mathrm{C}} 139.92 \mathrm{ppm}\right)$, and $\mathrm{H}-6$ $\left(\delta_{\mathrm{H}} 3.57 \mathrm{ppm}\right)$ with $\mathrm{C}-4 \quad\left(\delta_{\mathrm{C}} 152.12 \mathrm{ppm}\right), \mathrm{C}-8$ $\left(\delta_{\mathrm{C}} 77.31 \mathrm{ppm}\right), \mathrm{C}-11\left(\delta_{\mathrm{C}} 42.00 \mathrm{ppm}\right)$, and $\mathrm{H}-7$ $\left(\delta_{\mathrm{H}} 1.82 \mathrm{ppm}\right)$ with $\mathrm{C}-5 \quad\left(\delta_{\mathrm{C}} 52.59 \mathrm{ppm}\right), \mathrm{C}-11$ $\left(\delta_{\mathrm{C}} 42.00 \mathrm{ppm}\right), \mathrm{C}-13\left(\delta_{\mathrm{C}} 15.71 \mathrm{ppm}\right)$, and $\mathrm{H}-14$ $\left(\delta_{\mathrm{H}} 1.76 \mathrm{ppm}\right)$ with $\mathrm{C}-1 \quad\left(\delta_{\mathrm{C}} 44.87 \mathrm{ppm}\right), \mathrm{C}-9$ $\left(\delta_{\mathrm{C}} 125.43 \mathrm{ppm}\right), \mathrm{C}-10\left(\delta_{\mathrm{C}} 139.92 \mathrm{ppm}\right)$, and $\mathrm{H}-15$ $\left(\delta_{\mathrm{H}} 5.02,5.04 \mathrm{ppm}\right)$ with $\mathrm{C}-3\left(\delta_{\mathrm{C}} 35.02 \mathrm{ppm}\right), \mathrm{C}-5$ $\left(\delta_{\mathrm{C}} 52.59 \mathrm{ppm}\right)$. The relative stereochemistry of $\mathbf{2}$ was established from the coupling constants and NOESY experiments. The relative configuration and stereochemistry at C-5, C-6, and C-7 were derived from the coupling constants $\left(J_{5,6}=10.0 \mathrm{~Hz}\right.$ and $J_{6,7}=10.0 \mathrm{~Hz}$ ), indicating that the orientation of the protons is C-5 $(\alpha), \mathrm{C}-6(\beta)$, and C-7 $(\alpha)$. The NOESY experiments supported the proposed relative configuration; H-6 showed cross-peaks with $\mathrm{H}-1, \mathrm{H}-8$, and $\mathrm{H}-11$, indicating the $\beta$-orientation of these protons. Moreover, strong NOEs were observed between $\mathrm{H}-5, \mathrm{H}-7$, and $\mathrm{H}-2\left(\delta_{\mathrm{H}} 1.65 \mathrm{ppm}\right)$, suggesting the $\alpha$-orientation of these protons (Cheng et al., 2012). Therefore, compound 2 was identified as $6 \alpha$-hydroxy-5 $\alpha, 7 \alpha H$-guai-4(15),9(10)dien-12,8 $\alpha$-olide (Fig. 1), a new natural product.

The genus Inula has been reported as a rich source of sesquiterpenoids, including germacranes, eudesmanes, guaianes, pseudoguaianes, and xanthanes. Our previous work on I. verbascifolia afforded the isolation of two new xanthanes and a new germacrane (Ahmed et al., 2003), while in the present work two new guaianes were isolated, complementing the set of the previously reported compounds. Thus, the phytochemistry of $I$. verbascifolia is in agreement with that of the other species of the genus Inula. I. salsoloides afforded germacranolides (Jeske et al., 1996; Zhou et al., 1994); I. aschersoniana gave xanthanolides (Bloszyk et al., 1990), while I. hupehensis afforded pseudoguaianolides and guaianolides (Qin et al., 2011).

It is assumed that both the guaiane- and eudesmane-type lactones originate from a common germacrane precursor that is formed via the acetate-mevalonate-FPP (farnesyl pyrophosphate) pathway by a germacrene synthase, an enzyme belonging to the group of sesquiterpene cyclases (Herz, 1977; Bohlmann and Zdero, 1978; Fischer, 1990). Whether this common germacrane precursor is transformed into a guaiane skeleton or a eudesmane skeleton would depend on the position of enzyme-mediated epoxidations. A germacrene $\mathrm{C}-4-\mathrm{C}-5$ epoxide would lead to a guaiane, whereas a germacrene $\mathrm{C}-1-\mathrm{C}-10$ epoxide would lead to a eudesmane (Brown et al., 1975; Piet et al., 1995). The previously reported germacrene from I. verbascifolia was a germacrene C-4-C-5 epoxide (Ahmed et al., 2003), thus agreeing well with the two new guaianolides reported here.

\section{Experimental}

\section{General}

Optical rotations were measured on a PerkinElmer (Hiroshima, Japan) model 341 polarimeter with a $10-\mathrm{cm}$ cell. IR spectra were recorded on a JASCO (Hiroshima, Japan) FT/IR-5300 spectrometer. ${ }^{1} \mathrm{H}$ NMR $\left(600 \mathrm{MHz}, \mathrm{CDCl}_{3}\right),{ }^{13} \mathrm{C}$ NMR $\left(125 \mathrm{MHz}, \mathrm{CDCl}_{3}\right)$, and the 2D NMR spectra were recorded on a JEOL (Hiroshima, Japan) $500 \mathrm{MHz}$ Lambda spectrometer, with tetramethylsilane (TMS) as an internal standard. EI mass spectra were recorded on a JEOL SX102A mass spectrometer. Column chromatography (CC) was carried out on silica gel 60 (230-400 mesh; Merck, Darmstadt, Germany) and Sephadex LH-20 (Pharmacia Co., Tokyo, Japan). Thin-layer chromatography (TLC) was performed on silica gel $60 \mathrm{~F}_{254}$ plates $(0.25 \mathrm{~mm}$; Merck), and spots were detected under UV light and coloured by spraying with $10 \% \mathrm{H}_{2} \mathrm{SO}_{4}$ solution followed by heating.

\section{Plant material}

The aerial parts of $I$. verbascifolia were collected from Mt. Parnitha (Attiki), Greece and identified by Dr. Th. Constantinidis, Institute of Systematic Botany, Department of Biotechnology, Agricultural University of Athens, Athens, Greece. A voucher specimen of the collected material (No. I-1) has been deposited in the herbarium of the University of Patras, Patras, Greece.

\section{Extraction and isolation}

The air-dried aerial parts (500 g) of I. verbascifolia were powdered and extracted with 81 pure $\mathrm{CH}_{2} \mathrm{Cl}_{2}$ at room temperature. The extract was concentrated in vacuo to obtain a residue of $11 \mathrm{~g}$. The residue was fractionated by flash column chromatography $(5 \mathrm{~cm} \times 55 \mathrm{~cm})$ over silica gel $(1 \mathrm{~kg})$ eluting with $n$-hexane $(100 \%)$ with an increasing content of $\mathrm{CH}_{2} \mathrm{Cl}_{2}$ up to $100 \% \mathrm{CH}_{2} \mathrm{Cl}_{2}$. The $100 \%$ $n$-hexane fraction contained hydrocarbons and waxes. The second fraction ( $n$-hexane $/ \mathrm{CH}_{2} \mathrm{Cl}_{2}$, $1: 1,21)$ gave a crude material, which was further 
purified on Sephadex LH-20 $(3 \mathrm{~cm} \times 35 \mathrm{~cm} ; n$ hexane $/ \mathrm{CH}_{2} \mathrm{Cl}_{2} /$ methanol, $\left.7: 4: 0.5 ; 500 \mathrm{ml}\right)$ to give compound $1(9 \mathrm{mg})$. The third fraction $\left(\mathrm{CH}_{2} \mathrm{Cl}_{2}\right.$, $100 \%$ ) was further purified on Sephadex LH-20 (3 cm x $35 \mathrm{~cm} ; n$-hexane $/ \mathrm{CH}_{2} \mathrm{Cl}_{2} /$ methanol, 7:4:1; $500 \mathrm{ml})$ to afford compound $2(3 \mathrm{mg})$. The structures of $\mathbf{1}$ and $\mathbf{2}$ were determined by spectroscopic methods (IR, MS, ${ }^{1} \mathrm{H}$ NMR, ${ }^{13} \mathrm{C}$ NMR, DEPT, ${ }^{1} \mathrm{H}-{ }^{1} \mathrm{H}$ COSY, HMQC, and HMBC).

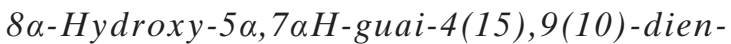
12,6aolide (1): $\mathrm{C}_{15} \mathrm{H}_{20} \mathrm{O}_{3}$. - Yellowish oil. $-[\alpha]_{\mathrm{D}}^{25}=$ $-20.88^{\circ}$ ( c 0.015, MeOH). - IR (KBr): $v=3471$ $(\mathrm{OH}), 1763 \mathrm{~cm}^{-1}(\mathrm{C}=\mathrm{O}) .-{ }^{1} \mathrm{H}$ NMR: The ${ }^{1} \mathrm{H}$ assignment were achieved by ${ }^{1} \mathrm{H}-{ }^{1} \mathrm{H}$ correlation spectroscopy (COSY), see Table I. $-{ }^{13} \mathrm{C}$ NMR: The ${ }^{13} \mathrm{C}$ assignments were achieved by HMQC and HMBC, see Table I. - MS (EI, $70 \mathrm{eV}$ ): $\mathrm{m} / \mathrm{z}$

Ahmed A. A., Mohamed A. H., Tzakou O., Petropoulou A., Mohamed E. H., Mohamed A. El-M., and Zeller K.-P. (2003), Terpenes from Inula verbascifolia. Phytochemistry 62, $1191-1194$.

Ball P. W. and Tutin T. G. (1976), Inula L. In: Flora Europaea, Vol. 4 (Tutin T. G., Heywood V. H., Burges N. A., Moore D. M., Valentine D. H., Walters S. M., and Webb D. A., eds.). Cambridge University Press, London, UK, p. 133.

Bloszyk E., Budesinsky M., Daniewski W. M., Peskova E., Drozdz B., and Holub M. (1990), Sesquiterpenic lactones of Inula aschersoniana. Collect. Czech. Chem. Commun. 55, $1562-1567$.

Bohlmann F. and Zdero C. (1977), Neue Sesquiterpenlactone und Thymol-Derivative aus Inula-Arten. Phytochemistry 16, $1243-1245$.

Bohlmann F. and Zdero C (1978), New sesquiterpenes and acetylenes from Athanasia and Pentzia species. Phytochemistry 17, 1595-1599.

Brown E. D., Sutherland J. K., and Sam T. W. (1975), Medium-ring 1:5-dienes. Part III. Cyclization of germacra-1(10),4,7-(11)-triene oxides. J. Chem. Soc. Perkin Trans I, 2332-2336.

Cheng X., Zeng Q., Ren J., Qin J., Zhang S., Shen Y., Zhu J., Zhang F., Chang R., Zhu Y., Zhang W., and Jin H. (2011), Sesquiterpene lactones from Inula falconeri, a plant endemic to the Himalayas, as potential anti-inflammatory agents. Eur. J. Med. Chem. 46, $5408-5415$

Cheng X.-R., Li W.-W., Ren J., Zeng Q., Zhang S.-D., Shen Y.-H., Yan S.-K., Ye J., Jin H.-Z., and Zhang W.D. (2012), Sesquiterpene lactones from Inula hookeri. Planta Med. 78, 465-471.

Chia N. C. and Hsin H. (2007), Isocostunolide, a sesquiterpene lactone, induces mitochondrial membrane
$(\%)=248(11)\left[\mathrm{M}^{+}\right], 230(83)\left[\mathrm{M}^{+}-\mathrm{H}_{2} \mathrm{O}\right], 215$

(13) $\left[\mathrm{M}^{+}-\mathrm{H}_{2} \mathrm{O}-\mathrm{CH}_{3}\right], 202$ (18), 201 (18), 105 (75); calcd. for $\mathrm{C}_{15} \mathrm{H}_{20} \mathrm{O}_{3} \mathrm{Na}$ 271.1310, found 271.1311.

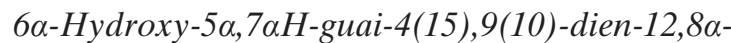
olide (2): $\mathrm{C}_{15} \mathrm{H}_{20} \mathrm{O}_{3}$. - Yellowish material. - IR $(\mathrm{KBr}): v=3475(\mathrm{OH}), 1754 \mathrm{~cm}^{-1}(\mathrm{C}=\mathrm{O}) .-{ }^{1} \mathrm{H}$ NMR: The ${ }^{1} \mathrm{H}$ assignments were achieved by ${ }^{1} \mathrm{H}$ ${ }^{1} \mathrm{H}$ correlation spectroscopy (COSY), see Table I. $-{ }^{13} \mathrm{C}$ NMR: The ${ }^{13} \mathrm{C}$ assignments were achieved by HMQC and HMBC, see Table I. - MS (EI, $70 \mathrm{eV}$ ): $m / z(\%)=248(10)\left[\mathrm{M}^{+}\right], 230(80)\left[\mathrm{M}^{+}-\mathrm{H}_{2} \mathrm{O}\right], 215$ (9) $\left[\mathrm{M}^{+}-\mathrm{H}_{2} \mathrm{O}-\mathrm{CH}_{3}\right], 105$ (71).

\section{Acknowledgements}

We are grateful to Prof. Ahmed A. Ahmed for his help and his assistance. depolarization and caspase-dependent apoptosis in human melanoma cells. Cancer Lett. 246, 237 - 252.

Fischer N. H. (1990), Sesquiterpene lactones: biogenesis and biomimetic transformations. In: Biochemistry of the Mevalonic Acid Pathway to Terpenoids (Towers G. and Towers H., eds.). Plenum Press, New York, USA, pp. 161-201.

Harvala E., Aligiannis N., Skaltsounis A. L., Pratsinis H., Lambrinidis G., Harvala C., and Chinou I. (2002), Cytotoxic germacranolides from Inula verbascifolia subsp. methanea. J. Nat. Prod. 65, 1045-1048.

Herz W. (1977), Sesquiterpene lactones in the compositae. In: The Biology and Chemistry of the Compositae (Heywood V. H., Harborne J. B., and Turner B. L., eds.). Academic Press, London, UK, pp. 337-357.

Hua Y., Qin J., Zhang F., Cheng X., Jin H., and Zhang W. (2012), Sesquiterpene lactones from Inula helianthusaquatica. Zhongguo Zhongyao Zazhi 37, 1586-1589.

Jeske F., Huneck S., and Jakupovi J. (1996), Further sesquiterpene lactones from Inula salsoloides. Phytochemistry 41, 1539-1542.

Kang J. K., Yoon Y. D., Lee K. H., Park S. K., and Kim H. M. (2004), Costunolide inhibits interleukin1beta expression by down-regulation of AP-1 and MAPK activity in LPS-stimulated RAW 264.7 cells. Biochem. Biophys. Res. Commun. 313, 171-177.

Konishi T., Shimada Y., Nagao T., Okabe H., and Konoshima T. (2002), Antiproliferative sesquiterpene lactones from the roots of Inula helenium. Biol. Pharm. Bull. 25, 1370-1372.

Li Y., Ni Z. Y., Zhu M. C., Dong M., Wang S. M., Shi Q. W., Zhang M. L., Wang Y. F., Huo C. H., Kiyota H., and Cong B. (2012), Activities of sesquiterpene lactones from Inula helenium and Inula japonica. Z. Naturforsch. 67c, $375-380$. 
Merxmüller H., Leins P., and Roessler H. (1977), Inuleae - Systematic review. In: The Biology and Chemistry of the Compositae (Heywood V. H., Harborne J. B., and Turner B. L., eds.). Academic Press, London, UK, pp. $577-602$.

Papano G., Malakov P., and Bohlmann F. (1980), $8 \beta$-Hydroxydihydroeremanthin: a new guaianolide from Inula aschersoniana. Phytochemistry 19, 152.

Piet D. P., Schrijvers R., Franssen M. C. R., and de Groot A. (1995), Biotransformation of germacrene epoxides by Cichorium intybus L. Tetrahedron 51, 6303-6314.

Qin J. J., Zhu J. X., Zeng Q., Cheng X. R., Zhu Y., Zhang S. D., Shan L., Jin H. Z., and Zhang W. D. (2011), Pseudoguaianolides and guaianolides from Inula hupehensis as potential anti-inflammatory agents. J. Nat. Prod. 74, $1881-1887$.
Qin J. J., Zhu J. X., Zeng Q., Cheng X. R., Zhang S. D., Jin H. Z., and Zhang W. D. (2012), Sesquiterpene lactones from Inula hupehensis inhibit nitric oxide production in RAW264.7 macrophages. Planta Med. 78, $1002-1009$.

Romo J., Rloa T., and Qwano L. (1968), Ligustrin, a guaianolide isolated from Europatorium ligustrinum DC. Tetrahedron 24, 6087-6091.

Won Y. K., Ong C. N., Shi X., and Shen H. M. (2004), Chemopreventive activity of parthenolide against UVB-induced skin cancer and its mechanisms. Carcinogenesis 25, 1449-1458.

Zhou B.-N., Bai N.-S., Lin L.-Z., and Cordell G. A. (1994), Sesquiterpene lactones from Inula salsoloides. Phytochemistry 36, 721-724. 